\title{
The Use of AR Illustration in the Promotion of Heritage Sites
}

\author{
Serena Fumero \\ Benedetta Frezzotti
}

\section{Abstract}

The course of Performative Techniques in Visual Arts (2020-2 I edition) at Libera Accademia d'Arte Novalia revolved around a project which saw students actively involved in the promotion of a local heritage site: the Precettoria (Abbey) of Sant'Antonio di Ranverso (Province of Turin). Despite its cultural relevance this site is little known, although the last few years saw an intense campaign for the promotion and restoration of the complex. The project completed during the course is part of this effort and the management of the site has been involved in its completion.

\section{Keywords}

augmented reality, heritage sites, Accademia Novalia, educational services.

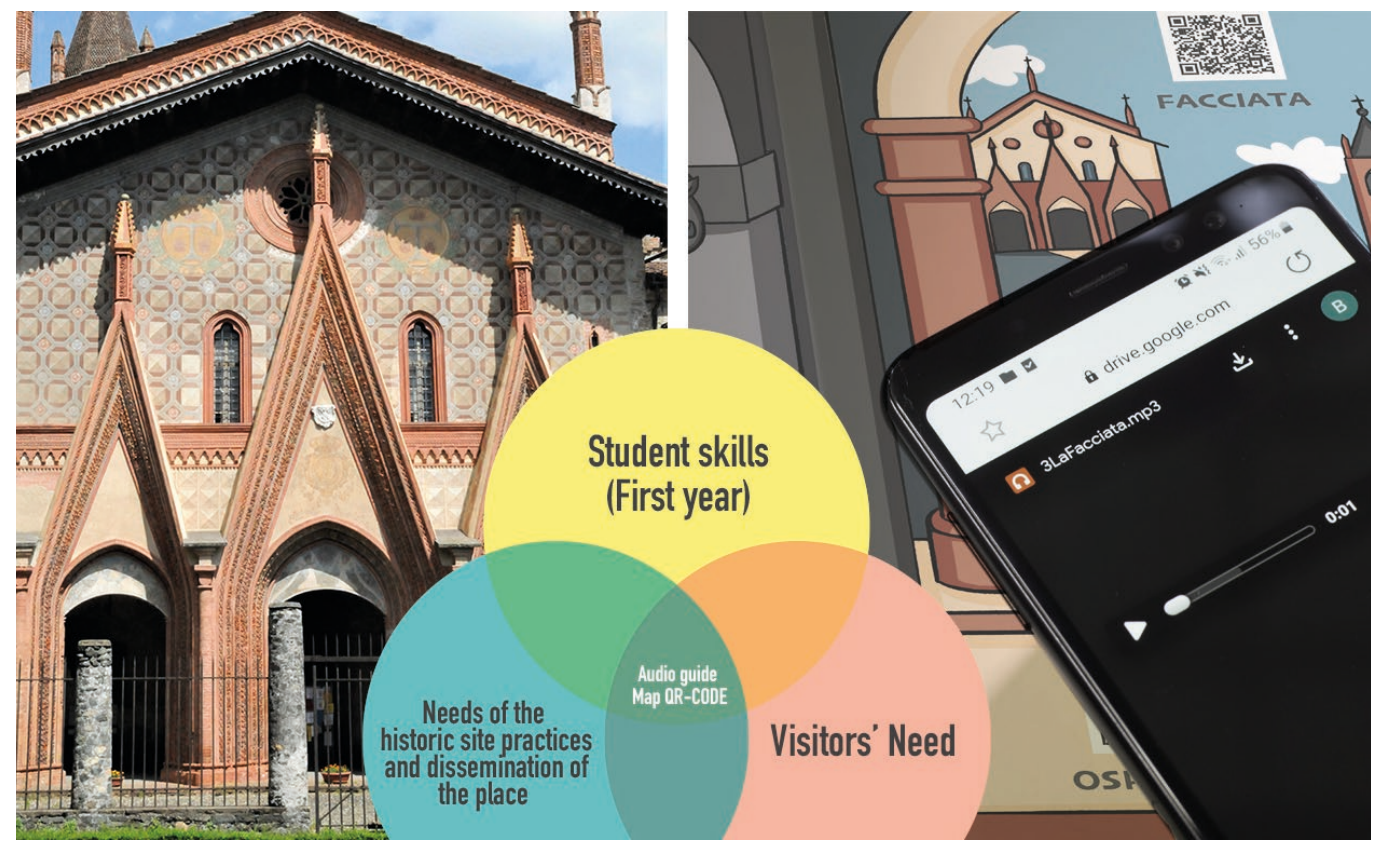




\section{Goals and Methodology}

Precettoria of Sant'Antonio di Ranverso:

Among the sites managed by the Fondazione Ordine Mauriziano [I], we decided to focus on the Precettoria of Sant'Antonio di Ranverso because this complex, located at the entrance of the Susa Valley [2], is a prestigious site whose late-Gothic architecture and rich and wonderful frescoes bring us back in time to the age of the Duchy of Savoy, between the dusk of the Middle Ages and the beginning of the Renaissance.

The social and historical relevance of the complex of Ranverso during the medieval period originated in 1188, when the Duke of Savoy offered the site to the Hospital Brothers of Saint Anthony. The members of the religious order hosted pilgrims and patients suffering from shingles (commonly referred to in Italian as fuoco di Sant'Antonio, meaning 'Sant Anthony's fire') and, later, from the plague. The Precettoria was conveniently located on the Via Francigena, the pilgrim route leading to Rome and some of the foremost religious sites of Christianity. Over the centuries, the entire complex has been rebuilt several times, while the church was completed during the last three decades of the I5th century, commissioned by Jean de Montchenou, who was named Prior in 1470. Back then, the complex included a hospital (of which only the façade is surviving), the church, and the Precettoria building. Of particular importance are the frescoes painted inside the church, depicting stories from the life of Saint Anthony the Great, the life of the Virgin Mary, the Passion of Christ, and the life of Saint Blaise of Sebaste, painted by Giacomo Jaquerio and his atelier in the first quarter of the 15th century: they are a true masterpiece of the International Gothic.

At the end of the I8th century, S. Antonio di Ranverso presided over a vast territory and, judging from the number of rural buildings, the surrounding area must have been considerably populated. By the time of the suppression of the Order of Saint Anthony in 1776, the territory administered by Sant'Antonio di Ranverso included almost a quarter of the area of the town of Buttigliera Alta, plus four farmsteads: all buildings and the land were assigned by the Pope Pius VI to the Ordine Mauriziano, and now belong to the Fondazione Ordine Mauriziano, a foundation who converted the site into a museum and is now safeguarding and promoting it.

Despite its cultural relevance, this site is little known: this is due to the lack of touristic promotion (which started only very recently) and the location of the Precettoria, which is currently cut off from public transportation. The restoration of the church, carried on between 2015 and 20 I7, has marked an important step: the lighting inside the church has been entirely redesigned, and a ticket office and a bookshop were added.

From the opening of the site to the public in June 2017, special efforts have been made to promote the visibility of the Precettoria, to establish educational services tailored for different visitors (from schools to families), and to use social media to reach potential visitors both in Italy and abroad. In this framework, the work carried out as part of the Performative Techniques in Visual Arts course at the Libera Accademia d'Arte Novalia [3], in collaboration with the site management, was marked by the signing of an agreement between the parties involved to grant the stu-




dents access to all the available study material and total freedom of action inside the complex. The project was carried out in two phases. Phase I was carried out on site, to assess the true extent of the tour of the entire complex - and not just of the church: it was immediately clear how an easily accessible audio-guide was key to fully understand the area and its surrounding, including the exterior of the building facing towards the Via Francigena, next to the hospital's façade.

Beyond a guided tour led by a museum curator, who is not always available, the only sources of information for the visitors were a few info pillars located inside the church, under the portico, and inside the cloister. We decided to create educational content and made them available to visitors; considering that the site is mainly toured by families with children, we aimed at engaging that specific audience.

Phase 2 was a detailed survey of the needs of the site, of the Accademia didactics, and of the users, which we can summarize as follows:

Precettoria of Sant'Antonio di Ranverso:

- Create an interactive guide available during the tour of the site;

- Minimize costs;

- Design an object for the museum shop;

- Not having info pillars, panels, or other structures installed on site.

Accademia didactics:

- Enhance the students' skills: the Accademia focuses on art techniques and the history of art, but not on coding (any need for that must have been outsourced, reducing the involvement of students in the project).

Users [4]

- Explore the site;

- Minimize costs;

- Not having apps installed on personal devices (because data plan costs, storage space issues, etc.)

- Engage children without resorting to tablets or mobile devices.

The data we collected have been analysed and used to evaluate the potential of different solutions, like info pillars with NFC chips, VR, AR with illustrated markers, AR with the mapping of existing elements to be used as markers, an e-book or in-app guide, and AR with QR codes. All potential solutions and technologies were tested and analysed by the students, as summarized in the following table:

\begin{tabular}{|c|c|c|c|c|c|c|c|c|}
\hline & & Guides & $\begin{array}{l}\text { Low cost } \\
\text { (for the site } \\
\text { management) }\end{array}$ & $\begin{array}{l}\text { Not having } \\
\text { apps installed } \\
\text { on personal } \\
\text { devices }\end{array}$ & $\begin{array}{l}\text { Low cost (for } \\
\text { users) }\end{array}$ & Children & $\begin{array}{l}\text { No info } \\
\text { pillars } \\
\text { needed }\end{array}$ & Shop \\
\hline $\begin{array}{l}\text { Info pillars } \\
\text { with NFC } \\
\text { chip }\end{array}$ & $x$ & $x$ & & $x$ & x & & & \\
\hline VR & & & & & $x$ & & & \\
\hline $\begin{array}{l}\text { AR } \\
\text { with } \\
\text { illustrated } \\
\text { markers }\end{array}$ & & $x$ & & & $x$ & & & $x$ \\
\hline $\begin{array}{l}\text { AR } \\
\text { with } \\
\text { mapping } \\
\text { of existing } \\
\text { elements }\end{array}$ & & $x$ & & & x & & $\mathrm{x}$ & \\
\hline $\begin{array}{l}\text { E-book } \\
\text { or in-app } \\
\text { guides }\end{array}$ & $x$ & $x$ & & & x & x & x & \\
\hline $\begin{array}{l}\text { AR with } \\
\text { QR code }\end{array}$ & x & $x$ & $x$ & $x$ & $x$ & $x$ & $x$ & x \\
\hline
\end{tabular}


As clearly shown, the only choice meeting all the criteria proved to be an illustrated map with QR codes linking to files from an audio-guide recorded by the students.

The project was carried out in 5 steps:

I) Production of all the assets needed to complete the project. First of all, the students visited the Precettoria and identified 8 points of interest along the visiting route, based on their relevance to the learning process related to the site: the goal was using them to build an itinerary both inside and outside the complex, to explain in very simple words the spirit of the place, the emotional journey of the pilgrims, the everyday life of the monks, and the work of the atelier of a major painter on the 15 th century frescoes.

2) Writing the audio-guide text and recording it. The language used is precise but accessible to everyone, including families with children.

3) Designing the map. We opted for an A4 size prioritizing illustrations, lowering printing cost but also making it user-friendly even for children. The map can be folded and held easily with one hand while holding a mobile device in the other.

4) Testing the map. As soon as the layout was ready, the students were asked to print a copy of the map and test the QR codes in low light conditions to ensure that they would work inside the Precettoria.

5) Production of the final map file, ready for printing.

\section{Discussion}

The $A R$ and $V R$ technologies are more and more widespread today, so there was much discussion about the opportunity of resorting to a simpler AR technology such as QR codes for this project, and if that might have led to a greater risk of obsolescence. The choice of QR codes was made to increase the degree of independence for students working on the project but also with the visitors of the Precettoria in mind: a comparatively low-tech product is far more suitable for their audience.
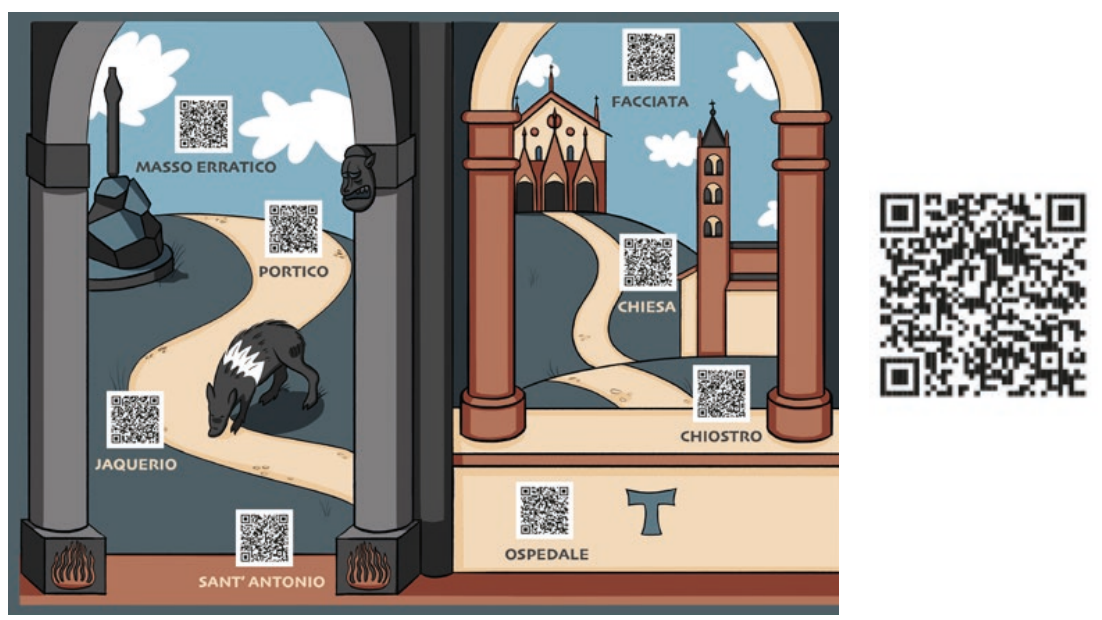

It took almost 10 years for $\mathrm{QR}$ codes to become widespread to the point where the vast public is now able to recognize them and use them with no need for specific instructions. QR codes are now printed on billboards for supermarkets' promotional sale, on school books used in primary schools, and even on menus, a growing use seen during the Covid-19 epidemic. Most of the mobile phones today don't need a specific app to read them: they can be read using a phone camera. This assessment led to the conclusion that QR codes are familiar and easily accessible to a vast and diversified public, while AR markers require a specific app and VR is not suitable for children under the age of 12 (and can be unpleasant for many adults). QR codes might also eventually be integrated with NFC chips for greater accessibility for visually impaired visitors. Furthermore, this technology is so common that the first survey about the implementation of QR codes in museums, promoted by the SMartArt [5] project, dates back to 2013. We can safely assume that $Q R$ codes will be the standard for museums in 
the near future. The main innovation in this project is where the QR codes are printed: not on info pillars or panels but on an illustrated map, a physical although low-cost object made more attractive by illustrations. The map is able to draw the attention of the visitors who, when they return to their homes, are still able to maintain a dialogue with the site thanks to the audio contents, which can be accessed and listened to anytime they want.

The students were considerably engaged by this project. Opting for a technology such as the QR code, so easy to use, didn't affect the visual and creative design but only the potential need for coding. The quality of the final works has been consistently high. Unfortunately the visitors' feedback has been delayed by the measures and restrictions in place during the current Covid-19 epidemic.

\section{Conclusions}

This project has proven extremely beneficial both for the didactics and for the Precettoria. We hope that the low cost and the relative ease of content production in this format will encourage a similar approach in many other heritage sites which, similarly to Sant'Antonio di Ranverso, are maybe little known but of great historical and artistic importance: similar contents can be implemented where a visiting itinerary is missing or to promote itineraries tailored for families or visitors belonging to specific categories. Regular updates will also help form a long-lasting relationship between the site and its visitors.

\section{Acknowledgements}

Our heartfelt thanks to the Precettoria of Sant'Antonio di Ranverso and the Fondazione Ordine Mauriziano for their support, but also to the students and management of the Libera Accademia d'Arte Novalia for carrying out the project despite the Covid-19 emergency and the sudden switch to remote learning.

\section{Notes}

[I] The site of the Precettoria belongs to F.O.M. Fondazione Ordine Mauriziano, a foundation whose aim is to protect and promote the Precettoria of Sant'Antonio di Ranverso, the Abbey of Staffarda and the Palazzina di Caccia of Stupinigi, which is a UNESCO World Heritage Site.

[2] In Buttigliera Alta (Province of Turin).

[3] The Libera Accademia d'Arte Novalia of Alba (https://novaliaarte.com/).

[4] Users' needs have been assessed based on the information collected from visitors and by creating fictional 'Personas'.

[5] QR-CODES in MUSEUMS, http://www.smart-art.it/qr-codes-museums/ (23 February 2021).

\section{References}

Bertea Cesare (1923). Sant’Antonio di Ranverso ed Avigliana.Torino: Stabilimento tipografico Ajani e Canale.

Devoti Chiara, Naretto Monica (20I0). Ordine e Sanità. Gli ospedali mauriziani tra XVIII e XX secolo: storia e tutela. Torino: Celid. Gritella Gianfranco (200 I). Il colore del gotico. I restauri della precettoria di Sant'Antonio di Ranverso. Savigliano: L'Artistica Editrice. Griseri Andreina (1966). Jaquerio e il Realismo Gotico in Piemonte. Torino: F.lli Pozzo Editore.

Mandarano Nicolette (2019). Musei e media digitali. Roma: Carocci Editore.

Molina Alfonso, Mannino Maria (20 I 6). Educazione per la vita e inclusione digitale. Strategie innovative per la scuola e la formazione degli adulti. Trento: Erickson.

\footnotetext{
Authors

Serena Fumero, Libera Accademia d'Arte Novalia of Alba, Precettoria of Sant'Antonio di Ranverso (Educational Services) Benedetta Frezzotti, Libera Accademia d'Arte Novalia of Alba, Studio Platypus - Milan, benedetta.frezzotti@studioplatypus.it
} 
